\title{
Analysis of new particle formation (NPF) events at nearby rural, urban background and urban roadside sites
}

\author{
Dimitrios Bousiotis ${ }^{1}$, Manuel Dall'Osto ${ }^{2}$, David C. S. Beddows ${ }^{1}$, Francis D. Pope ${ }^{1}$, and Roy M. Harrison ${ }^{1,3}$ \\ ${ }^{1}$ School of Geography, Earth \& Environmental Sciences and National Centre for Atmospheric Science, \\ University of Birmingham, Edgbaston, Birmingham B15 2TT, UK \\ ${ }^{2}$ Institute of Marine Sciences, CSIC, Passeig Marítim de la Barceloneta 37-49, 08003 Barcelona, Spain \\ 3 also at: Department of Environmental Sciences, Center of Excellence in Environmental Studies, \\ King Abdulaziz University, P.O. Box 80203, Jeddah, 21589, Saudi Arabia
}

Correspondence: Roy M. Harrison (r.m.harrison@bham.ac.uk)

Received: 3 October 2018 - Discussion started: 27 November 2018

Revised: 28 March 2019 - Accepted: 29 March 2019 - Published: 30 April 2019

\begin{abstract}
New particle formation (NPF) events have different patterns of development depending on the conditions of the area in which they occur. In this study, particle size distributions in the range of 16.6-604 nm (7 years of data) were analysed and NPF events occurring at three sites of differing characteristics - rural Harwell (HAR), urban background North Kensington (NK), urban roadside Marylebone Road (MR), London, UK - were extracted and studied. The different atmospheric conditions in each study area not only have an effect on the frequency of the events, but also affect their development. The frequency of NPF events is similar at the rural and urban background locations (about $7 \%$ of days), with a high proportion of events occurring at both sites on the same day ( $45 \%$ ). The frequency of NPF events at the urban roadside site is slightly less (6\% of days), and higher particle growth rates (average $5.5 \mathrm{~nm} \mathrm{~h}^{-1}$ at MR compared to 3.4 and $4.2 \mathrm{~nm} \mathrm{~h}^{-1}$ at HAR and NK respectively) must result from rapid gas-to-particle conversion of traffic-generated pollutants. A general pattern is found in which the condensation sink increases with the degree of pollution of the site, but this is counteracted by increased particle growth rates at the more polluted location. A key finding of this study is that the role of the urban environment leads to an increment of $20 \%$ in $N_{16-20 \mathrm{~nm}}$ in the urban background compared to that of the rural area in NPF events occurring at both sites. The relationship of the origin of incoming air masses is also considered and an association of regional events with cleaner air masses is found. Due to lower availability of condensable species, NPF events that are associated with cleaner at-
\end{abstract}

mospheric conditions have lower growth rates of the newly formed particles. The decisive effect of the condensation sink in the development of NPF events and the survivability of the newly formed particles is underlined, and influences the overall contribution of NPF events to the number of ultrafine particles in an area. The other key factor identified by this study is the important role that pollution, both from traffic and other sources in the urban environment (such as heating or cooking), plays in new particle formation events.

\section{Introduction}

Ultrafine particles (particles with diameter smaller than $100 \mathrm{~nm}$ ) typically make the greatest contribution in the total particle count, especially in urban environments (Németh et al., 2018), but a very small contribution to total volume and mass (Harrison et al., 2000). Research studies have indicated that ultrafine particles can cause pulmonary inflammation, may contribute to cardiovascular disease (Oberdörster, 2000) and have an increased possibility to penetrate the brain and central nervous system (Politis et al., 2008) compared to fine and coarser particles. Since some studies report that toxicity per unit mass increases as particle size decreases (Penttinen et al., 2001; MacNee et al., 2003; Davidson et al., 2005), it is considered possible that particle number concentrations may be a better predictor of health effects than mass concentrations (Harrison et al., 2000; Atkinson et al., 2010; Kelly et al., 2012; Samoli et al., 2016). Additionally, new particle for- 
mation (NPF) events have an impact on climate (Makkonen et al., 2012) either by increasing the number of cloud condensation nuclei (Spracklen et al., 2008; Merikanto et al., 2009; Dameto de España et al., 2017; Kalkavouras et al., 2017) or directly affecting the optical properties of the atmosphere (Seinfeld and Pandis, 2012).

The sources of ultrafine particles in urban areas can either be primary particles from emission sources such as traffic (Shi et al., 1999; Harrison et al., 2000), airports (Masiol et al., 2017) and other combustion-related processes (Keuken et al., 2015; Kecorius et al., 2016), or by NPF from gaseous precursors. New particle formation as described by Kulmala et al. (2014) is the process of production of low-volatility vapours, clustering of these vapours, nucleation, activation of the clusters with a second group of vapours and condensational growth to larger sizes. This process can occur both locally or on a larger scale; in the latter case the events are characterized as regional. Regional events have been found to take place on a scale of hundreds of kilometres (Németh and Salma, 2014; Shen et al., 2018), without being affected by air mass advection (Salma et al., 2016). NPF is one of the main contributors of particles in the atmosphere (Spracklen et al., 2010; Kulmala et al., 2016; Rahman et al., 2017) and this relative contribution increases when moving from a kerbside to a rural area (Ma and Birmili, 2015). While NPF events in rural and remote areas have been widely studied for many years (O'Dowd et al., 2002; Dal Maso et al., 2005; Ehn et al., 2010; Dall'Osto et al., 2017; Kalkavouras et al., 2017), in urban areas intensive studies have started mainly in recent years (Jeong et al., 2010; Minguillón et al., 2015; Peng et al., 2017; Németh et al., 2018). Early studies in Birmingham, UK, highlighted the connection of NPF events with solar radiation (Shi et al., 2001) and a low condensation sink (Alam et al., 2003), a measure of pre-existing aerosol loading (Dal Maso et al., 2002). The importance of a low condensation sink was further underlined by later studies as being one of the most influential variables in the occurrence of NPF in all types of environment (Wehner et al., 2007; Park et al., 2015; Pikridas et al., 2015). An important contributor to many NPF pathways is $\mathrm{SO}_{2}$ (Woo et al., 2001; Berndt et al., 2006; Laaksonen et al., 2008), which in the presence of solar radiation forms $\mathrm{H}_{2} \mathrm{SO}_{4}$, often the main component of the initial clusters (Kuang et al., 2008; Kulmala et al., 2013; Bianchi et al., 2016; Kirkby et al., 2016). Dall'Osto et al. (2013) pointed out that the role of $\mathrm{SO}_{2}$ is less significant in urban areas compared to rural and background areas. $\mathrm{SO}_{2}$ concentration variability in urban areas was found to have a small impact on the frequency of NPF events (Alam et al., 2003; Jeong et al., 2010), though it can have an effect on the number of particles formed (Charron et al., 2007). Furthermore, Dall'Osto et al. (2018) in their research at 24 sites in Europe pointed out the different role $\mathrm{SO}_{2}$ seems to play depending on its concentration, and that of other species. Jayaratne et al. (2017), however, found that in the heavily polluted environment of Beijing, China, NPF events were more probable in sulfur-rich conditions rather than sulfur-poor conditions. Apart from its role in the initial formation of the clusters, $\mathrm{H}_{2} \mathrm{SO}_{4}$ seems to participate in the early stages of growth of the newly formed clusters (Kulmala et al., 2005; Iida et al., 2008; Xiao et al., 2015). In later stages of growth, low or extremely low volatility organic compounds (O'Dowd et al., 2002; Laaksonen et al., 2008; Metzger et al., 2010; Kulmala et al., 2013; Tröstl et al., 2016; Dall'Osto et al., 2018) appear to be more important, while the role of ammonium nitrate in particle growth is also considered (Zhang et al., 2017). While in rural areas the organic compounds are mainly of biogenic origin (Riccobono et al., 2014; Kirkby et al., 2016), in urban areas they mainly originate from combustion processes (Robinson et al., 2007; Gentner et al., 2012). Many comparative studies have reported higher growth rates in urban areas compared to background sites (Wehner et al., 2007; Jeong et al., 2010; Salma, et al., 2016; Wang et al., 2017), as well as greater particle formation rates (Salma, et al., 2016; Nieminen et al., 2018) and a higher frequency of NPF events (Peng et al., 2017), which was attributed to the higher concentration of condensable species. Salma et al. (2014), however, reported fewer NPF events in the city centre of Budapest compared to the urban background, due to the higher condensation sink. Due to the complexity of the conditions and mechanisms within an urban area (Harrison, 2017), NPF events are harder to study and factors that drive them are harder to attribute. Increased concentrations of particles in the size range $1.3-3 \mathrm{~nm}$ were measured at a kerbside site when downwind from the road, following the trends in traffic-related nucleation mode particles, associating them with traffic emissions and thus not resulting from homogeneous nucleation mechanisms (Rönkkö et al., 2017; Hietikko et al., 2018); studies in Barcelona, Spain (Dall'Osto et al., 2012; Brines et al., 2014), and Leicester, UK (Hama et al., 2017), attributed a larger portion of nucleation mode particles to vehicular emissions compared to photochemically induced nucleation. As the condensation sink is higher within an urban environment, NPF events are less favoured. Their occurrence is attributed to either ineffective scavenging or the higher growth rate of the newly formed particles (Kulmala et al., 2017). The latter may occur when sufficient concentrations of precursors are present in the atmosphere (Fiedler et al., 2005), as particle formation was found to take place on both event and nonevent days with variable intensity. Particle formation though is not always followed by survival or growth of the newly formed particles and in such cases does not qualify as a NPF event (Riipinen et al., 2007).

In this study, NPF events in three areas of different land use in the southern UK are analysed. Studies for NPF events have been conducted in the past for Harwell, Oxfordshire (Charron et al., 2007, 2008), and the effect of NPF upon particle size distributions was also considered for North Kensington, London (Beddows et al., 2015). A combined study including all three sites has also been conducted, but in the aspect of ultrafine particle variation (Von Bismarck-Osten 


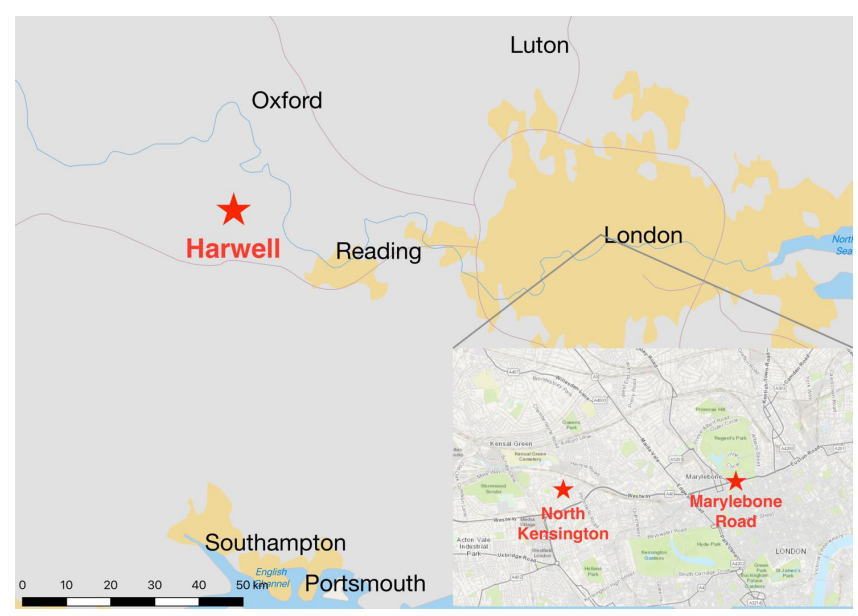

Figure 1. Map of the measuring stations.

et al., 2013). The present study is the first to use a combined long-term database for all three sites, focusing on the trends and conditions of NPF events at these sites, as well as the first which identifies NPF events at the high-traffic Marylebone Road site, as up to this point ultrafine particles were attributed only to traffic (Charron and Harrison, 2003; Dall'Osto et al., 2011). As in this study a rural and an urban background area are studied alongside a kerbside site in the city of London in close proximity, the conditions and development of NPF events in a mid-latitude European region are discussed in relation to the influence of different local environments.

\section{Data and methods}

\subsection{Site description and data availability}

This study analysed NPF events in three areas in the southern United Kingdom (Fig. 1). Harwell in Oxfordshire is located about $80 \mathrm{~km}$ west of the greater London area. The site is in the grounds of the Harwell Science Centre in Oxfordshire $\left(51^{\circ} 34^{\prime} 15^{\prime \prime} \mathrm{N}, 1^{\circ} 19^{\prime} 31^{\prime \prime} \mathrm{W}\right)$ and is representative of a rural background area; a detailed description of the site was given by Charron et al. (2013). North Kensington is a suburban area in the western side of London, UK, $4.5 \mathrm{~km}$ west of Marylebone Road. The site is located in the grounds of Sion Manning School $\left(51^{\circ} 31^{\prime} 15^{\prime \prime} \mathrm{N}, 0^{\circ} 12^{\prime} 48^{\prime \prime} \mathrm{W}\right)$ and is representative of the urban background of London. A detailed description of the site was given by Bigi and Harrison (2010). Marylebone Road is located in the centre of London, UK. The site is located on the kerbside of Marylebone Road $\left(51^{\circ} 31^{\prime} 21^{\prime \prime} \mathrm{N}\right.$; $0^{\circ} 9^{\prime} 16^{\prime \prime} \mathrm{W}$ ), a very busy arterial route within a street canyon. A more detailed description of the area can be found in Charron and Harrison (2003).

At all three sites, 7 years (2009-2015) of particle number size distributions in the range of 16.6-604 $\mathrm{nm}$ have been measured and recorded as 15 min averages, using a scanning mobility particle sizer (SMPS), comprised by an electrostatic classifier (EC, TSI model 3080) and a condensation particle counter (CPC, TSI Model 3775), operated on behalf of the UK Department for Environment, Food and Rural Affairs (DEFRA). At all sites the inlet air is dried, and the operation is in accordance with the EUSAAR/ACTRIS protocol (Wiedensohler et al., 2012). These 15 min measurements were averaged to an hourly resolution. In Harwell there were $46930 \mathrm{~h}$ of available SMPS data $(76.5 \%$ coverage), in North Kensington 51059 (83.3\% coverage) and at Marylebone Road 45562 (74.3\% coverage). Detailed data availability is found in Table S1 in the Supplement. A freestanding CPC (TSI model 3022A) was also operated alongside the EC for most of the years of the survey and was used to give an estimate of particles in the $7-16.6 \mathrm{~nm}$ range by difference from the SMPS.

Additionally, air pollutants and other gas and particle chemical composition data $\left(\mathrm{NO}_{x}, \mathrm{SO}_{2}, \mathrm{SO}_{4}^{2-}, \mathrm{Cl}, \mathrm{Na}, \mathrm{Mg}\right.$, gaseous ammonia and volatile organic compounds - VOCs) were extracted from the DEFRA website (https://uk-air. defra.gov.uk/, last access: 14 May 2018); daily measurements of particulate organic carbon (OC) were also extracted from the DEFRA website which are determined using the method described in the Annual report of the National Physical Laboratory (Beccaceci et al., 2015). Meteorological data for Harwell and Heathrow airport (used for North Kensington and Marylebone Road) were available from the Met Office, while solar radiation data from Benson station (for Harwell) and Heathrow airport (for North Kensington and Marylebone Road) were extracted from the Centre for Environmental Data Analysis (CEDA) site (http://www. ceda.ac.uk, last access: 16 May 2017). Back trajectory data calculated using the HYSPLIT model (Draxler and Hess, 1998) were extracted by the NOAA Air Resources Laboratory (https://ready.arl.noaa.gov/READYtransp.php, last access: 8 December 2017) and were processed using the Openair package for $\mathrm{R}$ (Carslaw and Ropkins, 2012).

\subsection{Methods}

\subsubsection{NPF events selection}

The identification of the NPF event days was made by visual inspection of SMPS data, supplemented with the use of CPC data to confirm the formation of a new mode of particles, using the criteria set by Dal Maso et al. (2005). NPF events are considered when a distinctly new mode of particles, which appears in the size distribution at nucleation mode size, prevails for some hours and shows signs of growth. Using these criteria, NPF events are classified into two classes, I and II depending on the level of certainty. Class I events are further classified to Ia and $\mathrm{Ib}$, with class Ia containing very clear and strong particle formation events, while Ib contains less clear events. In this study only the events of class Ia are consid- 
ered to be the most suitable for analysing case studies of NPF events (Fig. S1 in the Supplement). At this point it should be mentioned that due to the particle size range available, NPF events in which newly formed particles failed to grow beyond $16.6 \mathrm{~nm}$ (if any) could not be identified. Bursts of new particles in the size range $<16.6 \mathrm{~nm}$ that were identified using the CPC data but did not appear in the SMPS dataset were ignored as their development was unknown. This type of development was rare and mainly found at the rural background site, occurring on a few days per year mainly in summer. Its main feature was the short duration of the bursts compared to event days. In the urban sites, this type of development was almost non-existent. High time resolution data for gaseous pollutants and aerosol constituents were used to identify pollution events affecting particle concentrations and these were removed from the data analysis. This analysis took account of the fact that nanoparticle emissions from Heathrow Airport affect size distributions at London sites (Harrison et al., 2018), and such primary emission influences were not included as NPF events.

\subsubsection{Calculation of the condensation sink and growth rate}

For the calculation of the condensation sink the method proposed in Kulmala et al. (2001) was used in which the condensation sink is calculated as

$\mathrm{CS}=4 \pi D \sum \beta_{M} r N$,

where $r$ is the radius of the particles and $N$ is the number concentration of the particles. $D$ is the diffusion coefficient calculated (for $T=293 \mathrm{~K}$ and $P=1013.25 \mathrm{mbar}$ ) according to Kuuluvainen et al. (2010):

$$
D_{\text {vap }}=0.00143 \cdot T^{1.75} \frac{\sqrt{M_{\text {air }}^{-1}+M_{\text {vap }}^{-1}}}{P\left(D_{x, \text { air }}^{\frac{1}{3}}+D_{x, \text { vap }}^{\frac{1}{3}}\right)^{2}},
$$

where $P$ is air pressure, $M$ is the molar mass and $D_{x}$ is the diffusion volume for air and $\mathrm{H}_{2} \mathrm{SO}_{4}$. $\beta_{M}$ is the Fuchs correction factor calculated as follows (Fuchs et al., 1971):

$\beta_{M}=\frac{1+K n}{1+\left(\frac{4}{3 a}+0.377\right) K n+\frac{4}{3 a} K n^{2}}$,

where $K n$ is the relation of the particle diameter and the mean free path of the gas $\lambda_{m}$, called the Knudsen number.

The growth rate of the particles on nucleation event days was also calculated as proposed by Kulmala et al. (2012), using the formula

$\mathrm{GR}=\frac{D_{P_{2}}-D_{P_{1}}}{t_{2}-t_{1}}$

for the size range $16.6-50 \mathrm{~nm}$. The number of points taken depended on the development of the event and were considered from the start of the event until (a) growth stopped, (b) GMD reached $50 \mathrm{~nm}$ or (c) the day ended (this cut-off was chosen as the development of an event in its later stages is heavily biased by the local conditions, especially at the urban sites).

\subsubsection{Calculation of the urban increment (UI)}

The urban increment (UI) is defined as the ratio of the number concentration of particles below $20 \mathrm{~nm}$ for event days to the average (for the period April-October, when the majority of the events take place) for North Kensington to that at Harwell. This provides a measure of the new particles formed in each area in comparison to the average conditions, and is calculated by

$\mathrm{UI}=\frac{\mathrm{NK}_{\mathrm{Nuc} \text { Max }}-\mathrm{NK}_{\mathrm{Avg}}}{\mathrm{HW}_{\text {Nuc Max }}-\mathrm{HW}_{\mathrm{Avg}}}$,

where $\mathrm{NK}_{\mathrm{Nuc} \text { Max }}$ is the maximum concentration of particles below $20 \mathrm{~nm}$ found in the diurnal cycle on event days (found at 13:00 GMT) and $\mathrm{NK}_{\mathrm{Avg}}$ is the average mean concentration at the same time (same for Harwell in the denominator).

\subsubsection{Calculation of nucleation strength factor (NSF) and the $P$ parameter}

The nucleation strength factor (NSF) was proposed by Salma et al. (2014) as a measure of the effect nucleation events have in the composition of ultrafine particles in an area. Two factors were proposed. First is the NSF NUC. This is calculated as

$\mathrm{NSF}_{\text {NUC }}=\frac{\left(\frac{N_{\text {smallest size available-100 }}}{N_{\text {100-largest size available }}}\right)_{\text {nucleation days }}}{\left(\frac{N_{\text {smallest size available-100 }}}{N_{100} \text {-largest size available }}\right)}$

and provides of a measure of the concentration increment on nucleation days exclusively caused by NPF. The second factor is $\mathrm{NSF}_{\mathrm{GEN}}$ calculated as

$\mathrm{NSF}_{\mathrm{GEN}}=\frac{\left(\frac{N_{\text {smallest tize available-100 }}}{N_{100-\text { largest size available }}}\right)_{\text {all days }}}{\left(\frac{N_{\text {smallest size available-100 }}}{N_{\text {100-largest size available }}}\right)_{\text {non }- \text { nucleation days }}}$

and gives a measure of the overall contribution of NPF over a longer time span (Salma et al., 2017).

The dimensionless survival parameter $P$, as proposed in Kulmala et al. (2017), was calculated as

$P=\frac{\mathrm{CS}^{\prime}}{\mathrm{GR}^{\prime}}$,

where $\mathrm{CS}^{\prime}=\mathrm{CS} /\left(10^{-4} \mathrm{~s}^{-1}\right)$ and $\mathrm{GR}^{\prime}=\mathrm{GR} /\left(1 \mathrm{nmh}^{-1}\right)$. $\mathrm{CS}$ and GR values used were calculated with the methods mentioned at Sect. 2.2.2. An increased $P$ parameter is an indication that a smaller percentage of newly formed particles 


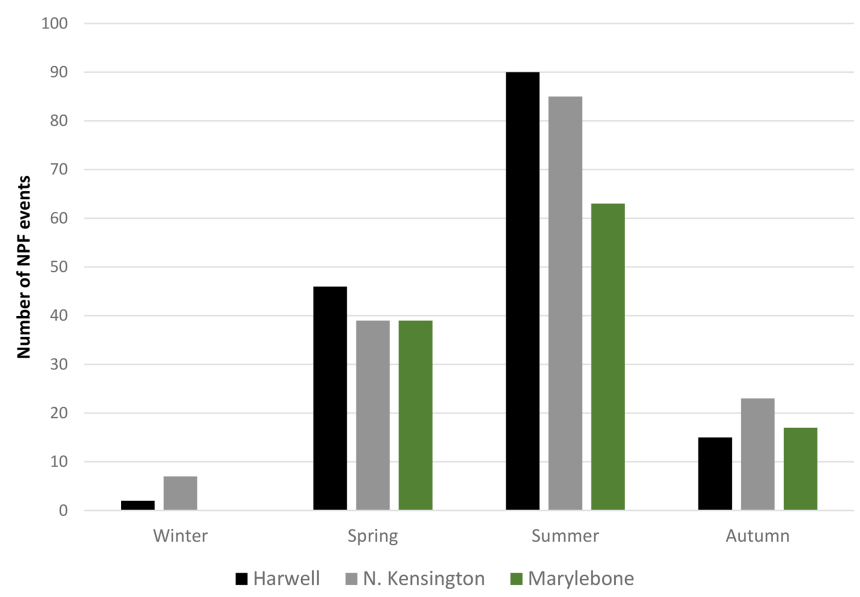

Figure 2. Number of NPF events per season for all 7 years of the present study (winter - DJF; spring - MAM; summer - JJA; autumn - SON) at Harwell (rural), North Kensington (urban background) and Marylebone Road (urban roadside).

will survive to greater sizes. Hence this is the inverse of particle survivability, and values of $P<50$ are typically required for NPF in clean or moderately polluted environments, although higher values of $P$ are observed in highly polluted atmospheres (Kulmala et al., 2017).

\section{Results and discussion}

\subsection{NPF events in the background areas}

\subsubsection{Conditions and trends of NPF events}

The number of NPF event days for each site per year, those that took place simultaneously at both urban and rural background sites, and those events that took place at all three sites simultaneously appear in Table 1 . Given that overall data recovery was in the range of $74 \%-83 \%$, results from individual years are unreliable, but the 7-year runs should average out most of the effects of incomplete data recovery. The number of events is similar for Harwell and North Kensington, with a frequency of about $7 \%$ of all days with data. There is a clear seasonal variation favouring summer and spring (Fig. 2) for both areas of the study. A similar pattern of variation was found for North Kensington by Beddows et al. (2015). In general, higher solar radiation, lower relative humidity, low cloud cover and higher pressure conditions, lower concentrations of pollutants, and lower condensation sinks are found when NPF events took place in all areas (Fig. S2), as was also reported by Charron et al. (2007) for Harwell. While $\mathrm{SO}_{2}$ is one of the main factors for NPF events to occur, concentrations are lower when events take place. This is indicative that $\mathrm{SO}_{2}$ concentrations in these areas are sufficient for events to take place, and higher concentrations are likely to be associated with higher pollution and a higher condensation sink.

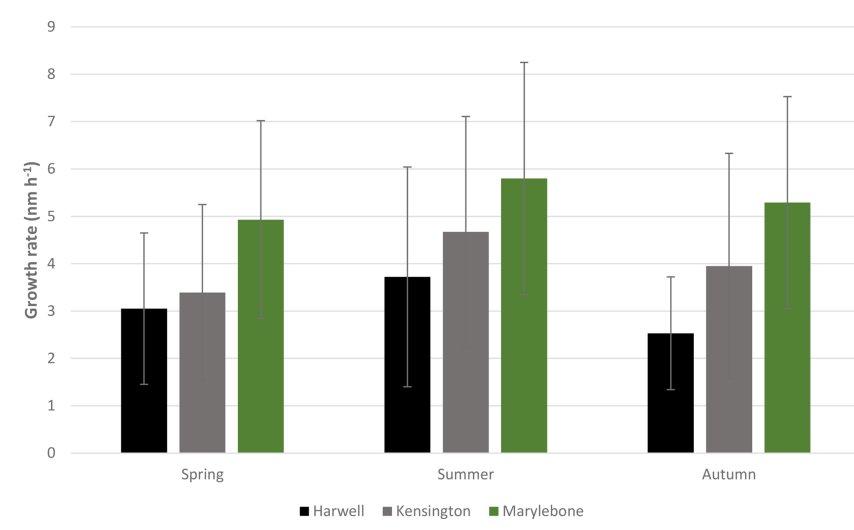

Figure 3. Growth rate per season at the three sites.

The proxy for $\left[\mathrm{H}_{2} \mathrm{SO}_{4}\right]$ was calculated for the background sites using the method outlined in Petäjä et al. (2009) and was found to be higher on event days for both background sites (results not included). This indicates the possible positive effect of increased concentrations of $\mathrm{H}_{2} \mathrm{SO}_{4}$ in the occurrence of NPF events as well as, since $\mathrm{SO}_{2}$ concentrations were found lower, the increased role of either the solar radiation (via the formation of $\mathrm{OH}$ radical) or the reduced condensation sink to its formation. For the case of gaseous ammonia (results not included) for Harwell where data were available, as there was no distinct variation found between event and non-event days, but as the concentration of ammonia in the UK is in the range of few parts per billion (Sutton et al., 1995), it is sufficient according to ternary nucleation theory (Korhonen et al., 1999) for NPF events not to be limited by ammonia. The average growth rate for Harwell was found to be $3.4 \mathrm{~nm} \mathrm{~h}^{-1}$, within the range given by Charron et al. (2007), and higher at North Kensington at $4.2 \mathrm{~nm} \mathrm{~h}^{-1}$, a trend found for all seasons (Fig. 3). The increased growth rate in the urban area can be related to the greater presence of organic matter and other condensable species. In both areas NPF events had higher growth rates in summer than in spring, as was also found in previous studies (Kulmala et al., 2004; Nieminen et al., 2018). This may be associated with the higher concentration of organic compounds emitted by trees during summer (Riipinen et al., 2007), or faster oxidation rates due to higher concentrations of hydroxyl radical and ozone (Harrison et al., 2006).

About $45 \%$ of the events took place simultaneously in both background areas. These events are characterized as regional, as NPF took place on a larger scale, regardless of the local conditions of the given area. In this case, meteorological conditions were even clearer, indicative of the greater dependence of regional events on synoptic conditions rather than local. While most chemical constituents were also lower in concentration during regional events, different patterns were found for organic compounds and sulfate for each background area. In Harwell sulfate was higher during regional events, while in North Kensington organic compounds were 
Table 1. Number of NPF events per site (in parenthesis the number of days with available data).

\begin{tabular}{lrrrrr}
\hline & Harwell & $\begin{array}{r}\text { N. } \\
\text { Kensington }\end{array}$ & $\begin{array}{r}\text { Marylebone } \\
\text { Road }\end{array}$ & $\begin{array}{r}\text { Regional } \\
\text { (background sites) }^{1}\end{array}$ & $\begin{array}{r}\text { Regional } \\
\text { (all 3 sites) }\end{array}$ \\
\hline 2009 & $9(210)$ & $0(332)$ & $4(290)$ & 0 & 0 \\
2010 & $29(262)$ & $22(310)$ & $22(292)$ & 11 & 9 \\
2011 & $15(291)$ & $10(300)$ & $23(284)$ & 4 & 1 \\
2012 & $8(334)$ & $28(303)$ & $12(140)$ & 3 & 0 \\
2013 & $25(328)$ & $23(342)$ & $27(334)$ & 13 & 11 \\
2014 & $29(324)$ & $34(330)$ & $13(314)$ & 11 & 6 \\
2015 & $25(282)$ & $22(314)$ & $18(338)$ & 60 & 37 \\
\hline Overall & $140(2031)$ & $139(2231)$ & $119(1993)$ & & 10 \\
\hline
\end{tabular}

${ }^{1}$ Refers to events occurring simultaneously at Harwell and North Kensington. ${ }^{2}$ Refers to events which occur simultaneously at all three sites.

higher during regional events. This may be indicative of the variable role that specific chemical species have in condensational nanoparticle growth (Yue et al., 2010). In all cases though, the concentrations of these species were lower compared to the average conditions. Despite these differences, the growth rate of particles was found to be higher for local events in North Kensington $\left(4.4 \mathrm{~nm} \mathrm{~h}^{-1}\right)$ compared to regional events $\left(3.9 \mathrm{~nm} \mathrm{~h}^{-1}\right)$, though within the margin of uncertainty. In Harwell, no difference was found in the growth rate between regional and local events.

\subsubsection{Urban increment and particle development}

The urban environment, depending on the conditions, may have a positive or negative effect in the number of the particles formed and their consequent survival and growth. Both Harwell and North Kensington are in background areas, rural and urban respectively. As a result, while the concentrations of pollutants are higher in North Kensington than Harwell, their effect is smaller compared to that of Marylebone Road. A comparison of the particles smaller than $20 \mathrm{~nm}$ gives insight into the formation and survival of the newly formed particles in the early stages. Calculating the urban increment (Eq. 5) using the two background sites showed around $20 \%$ more particles of size $16-20 \mathrm{~nm}$ in North Kensington than Harwell for event days, an increment that is even stronger when solely local events are considered (Fig. 4). As the sizes of the particles in the calculation are relatively large and due to the higher condensation sink found in North Kensington, this increment is expected to be larger for smaller size particles. A possible explanation for this result may be the greater concentration of organic compounds which is observed in North Kensington, as discussed earlier, which leads to more rapid formation of secondary condensable species that enhances the nucleation process in the more polluted area.

Considering the local events, most of the pollutant concentration data available appear to be higher, which is reflected in the condensation sink as well. The role of the polluted background appears to be decisive in the further growth of

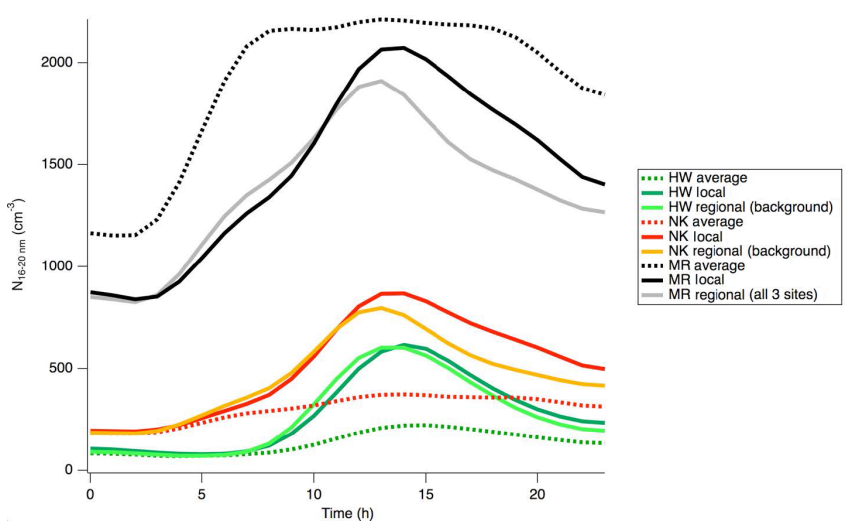

Figure 4. Diurnal variation of $N_{16-20 \mathrm{~nm}}$ at each site: annual mean and NPF event days.

the newly formed particles, especially for Harwell. At both sites, this causes the number of particles of greater size to be smaller for the later hours in the days of local events (Fig. S3). Another possible reason for this difference in the larger size ranges could be the higher concentration of organic content on the days of regional events at North Kensington (as discussed earlier). On the other hand, for Harwell all hydrocarbons with available data are lower throughout the day (apart from ethane) during regional events. Unlike North Kensington, at Harwell particles smaller than $20 \mathrm{~nm}$ as well as the growth rate of the newly formed particles are almost the same for regional and local events.

The calculation of the increment on Marylebone Road provided negative results; particles smaller than $20 \mathrm{~nm}$ were less abundant on event days compared to the average, throughout the day. This is due to the fact that Marylebone Road is heavily affected by traffic pollution and, on average, conditions do not promote NPF events due to the high condensation sink, unless clear conditions prevail, which are also associated with a low particle load. 


\subsection{NPF events at Marylebone Road}

For many years, NPF events were thought not to take place in heavily polluted urban areas, as the effect of the increased condensation sink was considered crucial in suppressing the formation and growth of new particles. Recent long-term analyses have shown this is not the case and nowadays an increasing number of studies confirm the occurrence of NPF events in urban areas. In this study, for the same period of 7 years as for the two background areas, NPF events were found to occur for $6.1 \%$ of days at Marylebone Road, lower than in the background areas. Though due to the particle size range available there cannot be a definitive answer to whether the formation of the particles takes place in the specific locality of the sampling site, due to the observed increase in particle concentrations in the range $7-16 \mathrm{~nm}$ (provided by the CPC data) and the increased growth rates found in urban areas in general, it can be assumed that the formation takes place either in the area of the measuring site or in its close vicinity, while the growth of the particles persists in the area for several hours, despite the high condensation sink. Seasonal variation is similar to that at the background sites, but day-of-the-week variation is stronger at Marylebone Road, further favouring weekends (Fig. S4), as on these days traffic intensity is lower.

In general, similar conditions found to affect NPF events at the background sites are also found at Marylebone Road, despite a much larger condensation sink (Fig. S2). As a result, less particles of size smaller than $20 \mathrm{~nm}$ were found on NPF event days than the average for the site, as the sum of background particles plus those formed on these days were less than that on an average day. The growth rate of the newly formed particles $\left(5.5 \mathrm{~nm} \mathrm{~h}^{-1}\right)$ is higher than that of the background sites, which is in agreement with the findings in the study of the background areas on the possible role of the condensable species, the concentrations of which are even greater at the urban kerbside. About $15 \%$ of NPF event days at Marylebone Road presented particle shrinkage after the initial growth; the study of these cases though is outside of the context of the present work. At Marylebone Road, the number of NPF days which were common with the background sites was fewer, as local conditions (high condensation sink) are detrimental to the occurrence of NPF events and thus the days of regional events including Marylebone Road were separately studied for this site. There were 37 regional event days that were common for all three sites (31\% of events at Marylebone Road) (Table 1). As with the other two areas, the growth rate is higher during local events, but the conditions are mixed, with lower concentrations of sulfate and organic compounds but higher $\mathrm{SO}_{2}, \mathrm{NO}_{x}$ and elemental carbon. The relationship with higher wind speed (mainly western; Fig. S6), solar radiation (which results in greater $\mathrm{H}_{2} \mathrm{SO}_{4}$ formation) and lower relative humidity indicates the stronger relation of the regional events with syn- optic conditions than the local events in the heavily polluted environment of Marylebone Road.

\subsection{Connection of NPF events with incoming air masses}

\subsubsection{Air mass back trajectory clustering and connection with NPF events}

The origin of the air masses plays a very important role in the occurrence of NPF events. Air masses of different origins have different characteristics. Back trajectories provide excellent insight into the source of the air masses. Air mass back trajectories were calculated both for all days and for NPF event days for each site separately. This analysis gives a view of the frequency of NPF events within different air mass types. The initial air mass back trajectory clustering ended up with an optimal solution of nine clusters of different air masses. As many of these clusters had similar characteristics and origin, solutions with fewer clusters were attempted. As the number of clusters was decreasing clusters became a mixture of different origins, thus making the distinction of different sources harder. As a result, the method chosen was to merge clusters of similar origin and characteristics, which kept the detail of the large number of clusters and made the separation of the different origins more distinct.

The resulting four merged clusters (Fig. 5), using the characterisation proposed by McIntosh et al. (1969), are as follows:

- An arctic cluster, which originates mainly from the northerly sector. It occurs about $10 \%$ of the time and consists of cold air masses, which either passed over northern parts of the UK or through the Irish Sea.

- A tropical cluster, which originates from the central Atlantic. It occurs $25 \%$ of the time and contains warmer air masses. A small percentage of this cluster contains masses that have passed over countries south of the UK. Even though these days were more polluted, the clustering method was unable to clearly distinguish these days as it does not take into account particle numbers or composition, even when the nine-cluster solution was applied.

- A polar cluster, which originates from the north Atlantic. It is the most common type of air mass arriving in the areas of study and occurs about $40 \%$ of the time, bringing fast-moving, "clean" air masses with increased marine components $(\mathrm{Cl}, \mathrm{Na}, \mathrm{Mg})$ from the west. This cluster also contains air masses that have passed through Ireland, though an effect on particle size and chemical composition is not distinct.

- A continental cluster, which originates from the east. It occurs about $25 \%$ of the time and consists mainly of slow-moving air masses, originating from the London 


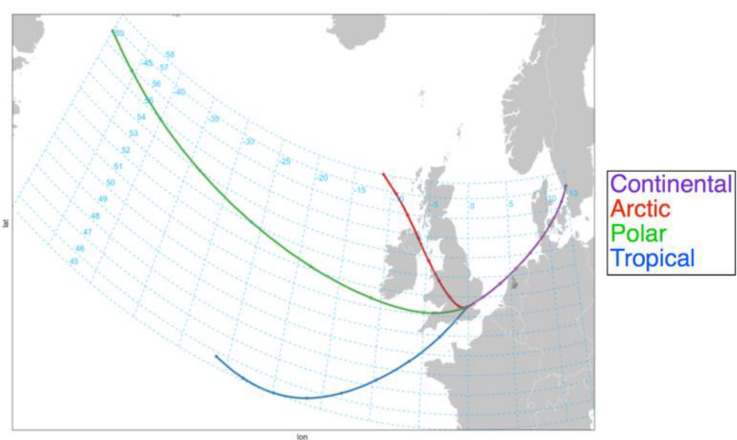

Frequency per air mass trajectory
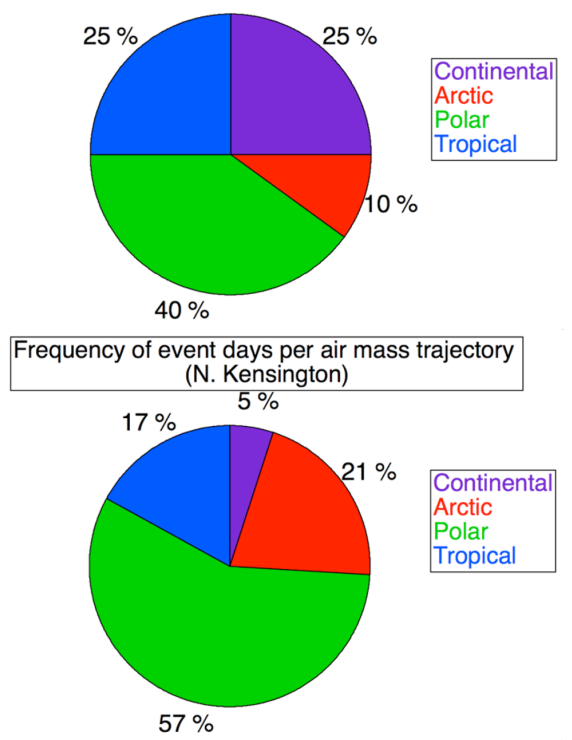
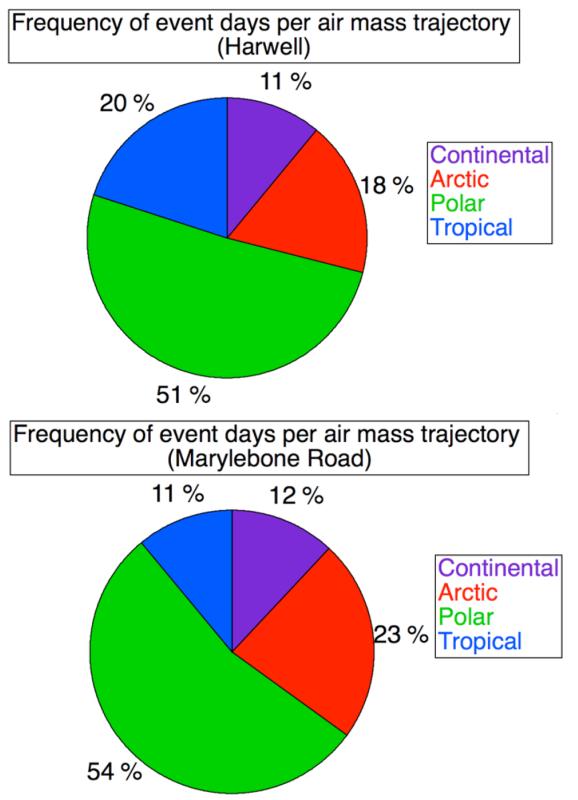

Figure 5. Map and frequency of incoming air mass origin - average and for NPF events per site.

area (for the background areas) and/or continental Europe. It has higher concentrations of most pollutants as well as the highest condensation sink.

The occurrence of each air mass class for average and event days for Harwell and London (both sites) can also be found in Fig. 5, while their main characteristics for each site can be found in Table S2. Though in this case the air mass grouping for each site was done in a different analysis, the resulting groups are almost identical in their characteristics and frequency, as the sites are close to each other.

The polar cluster is the one prevailing on both average and event days. This consists of clean fast-moving air masses originating mainly from middle and high latitudes of the Atlantic, and this cluster presents favourable conditions for NPF events. The association of NPF events with air masses from the mid-Atlantic at North Kensington was also found by Beddows et al. (2015). Cool Arctic air masses on average are not clean as they may have passed over the northern UK. The event days associated with this air mass type have the lowest concentrations of the pollutants within available data for all areas. The increased percentage of events with this air mass at all sites indicates that lower temperatures, in a clear atmosphere with sufficient solar radiation, are favourable for NPF events as found in previous studies (Napari et al., 2002; Jeong et al., 2010; Kirkby et al., 2011). A similar trend of increased probability with polar and arctic maritime air masses was also found for Hyytiälä, Finland, by Nilsson et al. (2001). Tropical air masses have a lower probability for NPF events, which is associated with the fact that a number of these days are associated with air masses which have passed from continental areas south of the UK (France, Spain etc.). Specifically for Marylebone Road the NPF probability is a lot lower (11\% versus $17 \%$ for North Kensington and $20 \%$ for Harwell). This is due to the fact that these air masses are more related to southerly winds which on Marylebone Road are associated with a street canyon vortex which causes higher pollutant concentrations at this site. Finally, the Continental cluster presents the lowest probability for NPF events. The air masses in this group originate from continen- 


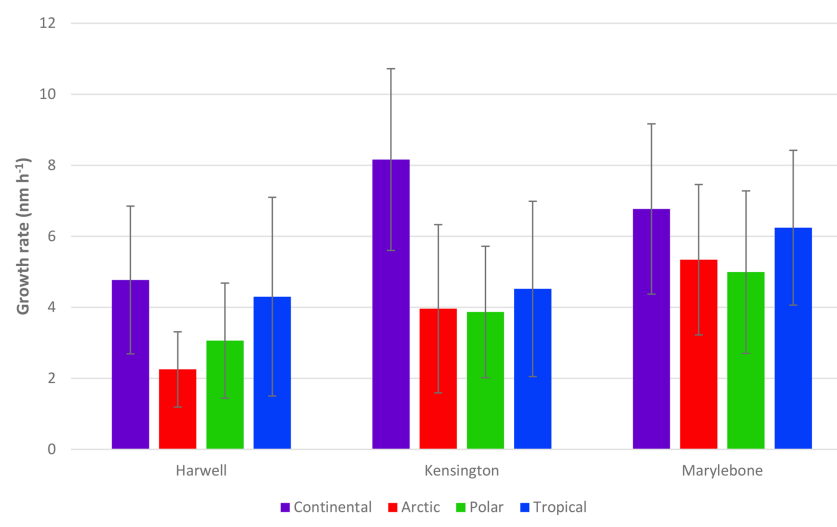

Figure 6. Growth rate per incoming air mass origin at each of the sites.

tal Europe and for the background areas in most cases have passed over the London region as well. This results in both a higher condensation sink and concentration of pollutants, which limits the number of days with favourable conditions for NPF events. The growth rate for all sites though appears to be higher for air masses originating from more polluted areas (Fig. 6), which appear to enhance the growth process due to containing a higher concentration of condensable species (after oxidation).

\subsubsection{Variability of the origin of the air masses on NPF events}

As both background sites are relatively close to each other (about $80 \mathrm{~km}$ ) and had a similar number of event days, a combined clustering of back trajectories for the event days (only) in these two areas was attempted. This would provide an insight into the origin of air masses for local and regional events, as well as the conditions for these air masses. The data for local North Kensington events and both local and regional events in Harwell were clustered together and the results along with the characteristics of the air mass clusters are found in Fig. S5.

Cluster $\mathrm{C} 3$, which is placed between $\mathrm{C} 2$ and $\mathrm{C} 4$ among those originating from the Atlantic Ocean, has the highest percentage for both area-specific and regional events. Specifically, for regional events the percentage is over $35 \%$, much higher compared to all others, showing a clear "preference" of regional events for cleaner and faster-moving air masses from mid-latitudes of the Atlantic Ocean. This "preference" explains the lower production and growth rate of the new particles found for regional events, compared to local ones, as for air masses from this area lower organic carbon and $\mathrm{SO}_{2}$ concentrations were found at both sites in this study. Cluster $\mathrm{C} 5$, originating straight from the north but representing air masses that have crossed the Irish Sea and have not extensively gone over land, presents a similar case. These cold and clean air masses are associated with a low growth rate
Table 2. Annual and seasonal NSF for all areas of study.

\begin{tabular}{lrrr}
\hline & Harwell & $\begin{array}{r}\text { N. } \\
\text { Kensington }\end{array}$ & $\begin{array}{r}\text { Marylebone } \\
\text { Road }\end{array}$ \\
\hline NSF $_{\text {NUC }}$ (spring) & $2.04 \pm 0.69$ & $2.03 \pm 0.51$ & $1.20 \pm 0.25$ \\
$\mathrm{NSF}_{\text {NUC }}$ (summer) & $2.01 \pm 0.85$ & $1.72 \pm 0.52$ & $1.26 \pm 0.36$ \\
$\mathrm{NSF}_{\text {NUC }}$ (year) & $2.25 \pm 0.85$ & $1.86 \pm 0.56$ & $1.26 \pm 0.31$ \\
$\mathrm{NSF}_{\text {GEN (spring) }}$ & $1.10 \pm 0.64$ & $1.07 \pm 0.59$ & $1.02 \pm 0.29$ \\
$\mathrm{NSF}_{\text {GEN (summer) }}$ & $1.18 \pm 0.72$ & $1.11 \pm 0.55$ & $1.01 \pm 0.25$ \\
$\mathrm{NSF}_{\text {GEN (year) }}$ & $1.10 \pm 0.61$ & $1.06 \pm 0.54$ & $1.02 \pm 0.27$ \\
\hline
\end{tabular}

and consequently low survivability of the newly formed particles. Local events for both sites apart from those in Cluster $\mathrm{C} 3$ are highly associated with Clusters $\mathrm{C} 1$ and $\mathrm{C} 2$. $\mathrm{C} 1$, which contains slow and polluted air masses, presents the highest growth rate and as a result high particle survivability, as given by the $P$ parameter (see later). On the other hand, $\mathrm{C} 2$, which consists of warm and moist air masses from lower latitudes, is the least common for regional events and presents a high growth rate and survival probability of the particles. Apart from the weak relation found with particulate organic carbon concentrations and growth rate (Fig. S5), there appears to be an inverse relation between the temperature and survivability of the particles. Warmer air masses seem to be related to higher particle survival probability, which may be attributable to greater growth rates as temperature increases (Yli-Juuti et al., 2011).

\subsection{Nucleation strength factor (NSF)}

The NSF (Eqs. 6 and 7) is used to describe the effect nucleation events have on the number of particles at a site. The values of NSF for each site and for spring and summer are shown in Table 2. The decrease in the contribution of NPF events to particle number, moving from the rural area to the kerbside was also found in previous studies (Salma et al., 2014, 2017). This is explained by the increased contribution to the particle number concentrations of other sources, mainly combustion in the urban environment, compared to rural areas. Apart from this trend, in the background areas the increase in $N_{16-100}$ was greater in spring than summer. This effect seems stronger in the urban background area compared to the rural, as in that area the variability of $N_{16-100}$ is greater for event days compared to that of the rural area. On the other hand, the contribution of NPF events in the longer term, as is illustrated by the $\mathrm{NSF}_{\mathrm{GEN}}$, appears to favour summer for all areas, showing the increased formation and survivability of particles in this season.

For Marylebone Road the result for the increase in the $N_{16-100}$ is greater in summer than in spring, in contrast to what was found for the background sites. This is due to the fact that in summer the traffic intensity is decreased, giving the contribution from NPF events a stronger effect compared to the other sources. The very small increase found in NPF 
(a)

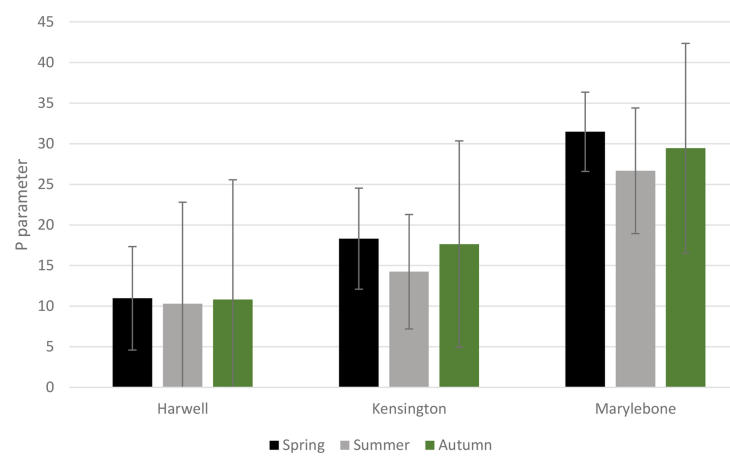

(b)

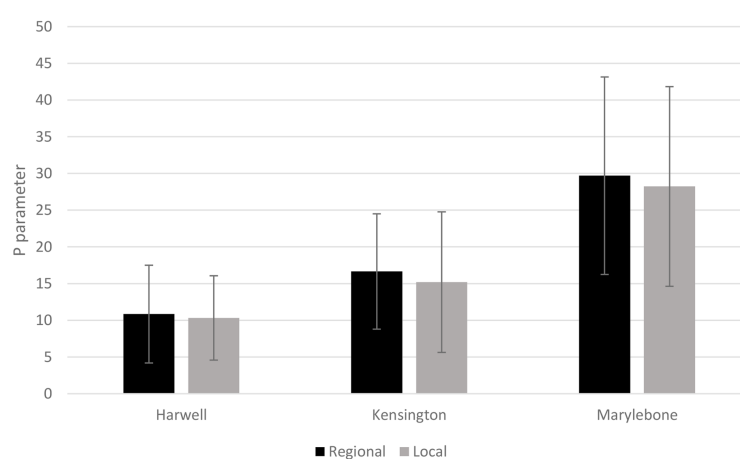

(c)

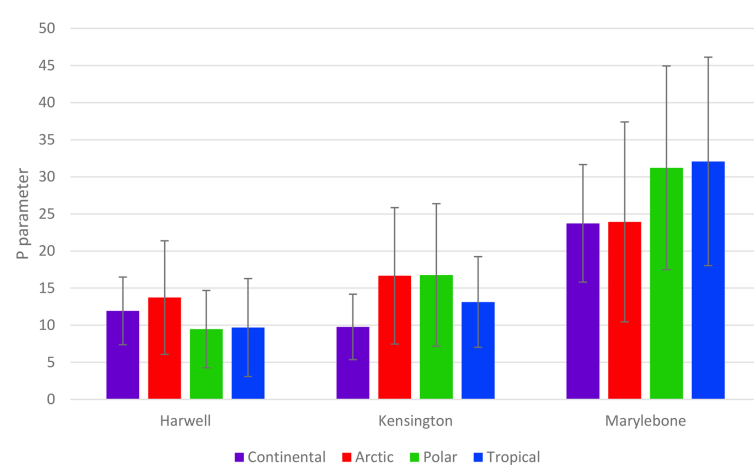

Figure 7. Survival parameter $P$ (a) per season, (b) for regional and local events (for Marylebone Road regional is for all three sites), and (c) by incoming air mass origin.

events on Marylebone Road, with a factor of just 1.26, a lot lower than that found in the urban area of Seoul, South Korea (Park et al., 2015), is indicative of the reduced effect of NPF events in an area which is heavily affected by traffic, as also pointed out by Von Bismarck-Osten et al. (2013) in their study on particle composition on Marylebone Road.

\subsection{The survival parameter $P$}

The average values of the $P$ parameter for each of the areas of this study are 10.5 for Harwell, 15.8 for North Kensington and 28.9 for Marylebone Road. The values found place Marylebone Road at the upper end of heavily polluted areas in Europe and North Kensington at the same level as many other urban areas in Europe, while Harwell somehow had higher values compared to other rural background areas in Europe, as calculated by Kulmala et al. (2017). The seasonal, air mass origin and local-versus-regional variations can be found in Fig. 7 (winter is excluded due to very low number of events). While the increasing trend of the $P$ parameter as we move from rural background to kerbside was expected, it can be seen that there is a clear seasonal pattern in all three areas, with summer having the lowest $P$ parameter (greatest survivability) compared to the other two seasons. This is associated with the higher growth rate found in summer for all areas of this study, as the differences in the condensation sink on event days are negligible between seasons. The case is similar for regional and local events. The result per air mass origin is related to the different conditions and parameters of each incoming air mass in each area. For example, the higher $P$ parameter for tropical air masses at Marylebone Road is associated with the higher condensation sink found for this kind of air mass, due to the street canyon effect which is specific for Marylebone Road for southerly wind directions with which these air masses are mainly related, while the higher values for the rather clean Arctic air masses for the other two areas are associated with the lower growth rates found for this kind of air mass in these areas. The more polluted continental air masses seem to have a different effect for rural and urban areas. Their higher condensation sinks and concentrations of pollutants have a negative effect on $P$ values for the rural site and a positive effect at the urban sites. The exact opposite is found for the cleaner air masses of the Polar cluster, which appear to result in reduced $P$ values of the newly formed particles at the urban sites. This is related to the lower condensation sink associated with this air mass type.

\section{Conclusions}

A total of 7 years of particle size distributions in the range 16.6-604 $\mathrm{nm}$ and other meteorological and chemical composition data from three distinct areas (regional background, urban background, kerbside) in the southern UK were analysed and the conditions associated with NPF events were studied. NPF events were found to occur on about $7 \%$ of days at background sites and less at the kerbside site. The conditions on event days for all three areas were similar, with clear atmospheric conditions and a lower condensation sink. While the condensation sink appears to be the most important factor limiting NPF events at the kerbside site, $\mathrm{SO}_{2}$ was found to have smaller concentrations on event days for all areas, which indicates that either on average it is in sufficient concentrations for NPF events to occur, or that other variables that participate in the production mechanism of $\mathrm{H}_{2} \mathrm{SO}_{4}$ are more important. The growth rate of the newly formed particles increases from the rural site to the kerbside and is greater in summer compared to other seasons for all three sites. Almost half of the NPF events at the rural and urban background sites were found to happen simultaneously. In 
these cases, the atmospheric conditions were cleaner, which resulted in slower growth rates. While most of the chemical species available were at lower concentrations in regional events, a difference in the behaviour with respect to sulfate and organic compounds was found between the two background site types.

The prevailing origin of air masses in the southern UK is from middle and high latitudes of the Atlantic Ocean. These fast-moving air masses present an increased probability for NPF to occur. The case is similar for the cooler and cleaner arctic air masses, while air masses from the tropics and continental Europe, having greater pollutant content, have decreased NPF probability, but a higher growth rate of particles when NPF events occurred. Regional events appear to be more associated with cleaner air masses, presenting a smaller growth rate and condensation sink compared to local events. The difference in growth rate is probably related to the greater content of condensable species; a positive relation of particle survival probability with temperature was also found.

Comparing the background areas in this study, particles of 16-20 nm were found to be about $20 \%$ greater in concentration (above long-term average) on NPF event days at the urban background site compared with the rural site. This is associated with a higher abundance of condensable species in the urban environment, which enhances the nucleation and growth process. This effect though is limited as particle size increases and NPF events have a greater effect on the overall $N_{<100 \mathrm{~nm}}$ in the rural areas, compared to urban areas, as calculated by the NSF. The effect becomes even smaller at the kerbside as the number of background particles emitted by traffic is a lot greater.

The occurrence of NPF events at the highly polluted Marylebone Road site is at first sight surprising given the elevated condensation sink. This must be counteracted by an abundance of condensable material, which is surprising given the generally modest rate of atmospheric oxidation processes in comparison to residence times in a street canyon (Harrison, 2017). However, Giorio et al. (2015), using aerosol timeof-flight mass spectrometry, reported rapid chemical processes within the Marylebone Road street canyon leading to production of secondary particulate matter from road traffic emissions. They postulated that this resulted from very local gas-to-particle conversion from vehicle-emitted pollutants. Condensation of such reaction products upon pre-existing particles could explain the enhanced particle growth rates observed at Marylebone Road (Fig. 3).

Finally, particle survival probability was found to decrease moving from rural to urban areas. While formation and initial growth of new particles is increased in urban areas, their survivability reduces as their size increases. The probability of particles to survive to greater sizes was found to be increased in summer for all areas, which is also explained by the higher growth rate. The probability is also different de- pending upon the origin of the air masses and is related to conditions specific for each area.

In the present work, the effects of atmospheric conditions upon the NPF process are studied. NPF is a complex process, highly affected by meteorological conditions (local and synoptic), the chemical composition and the pre-existing conditions in an area. For this reason, the study of NPF events in one area cannot provide safe assumptions for other areas, as the mixture of conditions found in different places is unique and alters the occurrence and development of NPF events. Thus, more studies on the conditions and the trends in NPF events should be conducted to better understand the effect of the numerous variables that affect those processes.

Data availability. Data supporting this publication are openly available from the UBIRA eData repository at https://doi.org/10. 25500/edata.bham.00000307 (Bousiotis and Harrison, 2019).

Supplement. The supplement related to this article is available online at: https://doi.org/10.5194/acp-19-5679-2019-supplement.

Author contributions. This study was conceived by MDO and $\mathrm{RMH}$, who also contributed to the final paper. The data analysis was carried out by DB with guidance from DCSB, and DB also prepared the first draft of the manuscript. FDP provided advice on the analysis.

Competing interests. The authors declare that they have no conflict of interest.

Acknowledgements. The authors acknowledge financial support (to DCSB) from the Natural Environment Research Council's funding of the National Centre for Atmospheric Science (NCAS) (grant number R8/H12/83/011).

Review statement. This paper was edited by Tuukka Petäjä and reviewed by two anonymous referees.

\section{References}

Alam, A., Shi, J. P., and Harrison, R. M.: Observations of new particle formation in urban air, J. Geophys. Res.-Atmos., 108, 40934107, https://doi.org/10.1029/2001JD001417, 2003.

Atkinson, R. W., Fuller, G. W., Anderson, H. R., Harrison, R. M., and Armstrong, B.: Urban ambient particle metrics and health: A time-series analysis, Epidemiology, 21, 501-511, 2010.

Beccaceci, S., McGhee, E., Robins, C., Butterfield, D., Tompkins, J., Quincey, P., Brown, R., Green, D., Tremper, A., Priestman, M., and Font Font, A.: Airborne particulate concentrations and numbers in the United Kingdom (phase 3), available at: http: 
//uk-air.defra.gov.uk/library/reports?section_id=13 (last access: 22 March 2019), 2015.

Beddows, D. C. S., Harrison, R. M., Green, D. C., and Fuller, G. W.: Receptor modelling of both particle composition and size distribution from a background site in London, UK, Atmos. Chem. Phys., 15, 10107-10125, https://doi.org/10.5194/acp-15-101072015, 2015.

Berndt, T., Böge, O., and Stratmann, F.: Formation of atmospheric $\mathrm{H}_{2} \mathrm{SO}_{4} \mathrm{H}_{2} \mathrm{O}$ particles in the absence of organics: A laboratory study, Geophys. Res. Lett., 33, 2-6, 2006.

Bianchi, F., Trostl, J., Junninen, H., Frege, C., Henne, S., Hoyle, C. R., Molteni, U., Herrmann, E., Adamov, A., Bukowiecki, N., Chen, X., Duplissy, J., Gysel, M., Hutterli, M., Kangasluoma, J., Kontkanen, J., Kurten, A., Manninen, H. E., Munch, S., Perakyla, O., Petaja, T., Rondo, L., Williamson, C., Weingartner, E., Curtius, J., Worsnop, D. R., Kulmala, M., Dommen, J., and Baltensperger, U.: New particle formation in the free troposphere: A question of chemistry and timing, Science, 352, 1109-1112, 2016.

Bigi, A. and Harrison, R. M.: Analysis of the air pollution climate at a central urban background site, Atmos. Environ., 44, 2004 2012, 2010.

Bousiotis, D. and Harrison, R. M.: NPF UK Data, available at: https://doi.org/10. 25500/edata.bham.00000307, last access: 13 February 2019.

Brines, M., Dall'Osto, M., Beddows, D. C. S., Harrison, R. M., and Querol, X.: Simplifying aerosol size distributions modes simultaneously detected at four monitoring sites during SAPUSS, Atmos. Chem. Phys., 14, 2973-2986, https://doi.org/10.5194/acp14-2973-2014, 2014.

Carslaw, D. C. and Ropkins, K.: openair - An R package for air quality data analysis, Environ. Modell. Softw., 27, 52-61, 2012.

Charron, A. and Harrison, R. M.: Primary particle formation from vehicle emissions during exhaust dilution in the roadside atmosphere, Atmos. Environ., 37, 4109-4119, 2003.

Charron, A., Birmili, W., and Harrison, R. M.: Factors influencing new particle formation at the rural site, Harwell, United Kingdom, J. Geophys. Res.-Atmos., 112, D14210, https://doi.org/10.1029/2007JD008425, 2007.

Charron, A., Birmili, W., and Harrison, R. M.: Fingerprinting particle origins according to their size distribution at a UK rural site, J. Geophys. Res.-Atmos., 113, D07202, https://doi.org/10.1029/2007JD008562, 2008.

Charron, A., Degrendele, C., Laongsri, B., and Harrison, R. M.: Receptor modelling of secondary and carbonaceous particulate matter at a southern UK site, Atmos. Chem. Phys., 13, 1879-1894, https://doi.org/10.5194/acp-13-1879-2013, 2013.

Dal Maso, M., Kulmala, M., Lehtinen, K. E. J., M'kelä, J. M., Aalto, P., and O'Dowd, C. D.: Condensation and coagulation sinks and formation of nucleation mode particles in coastal and boreal forest boundary layers, J. Geophys. Res.-Atmos., 107, 8097, https://doi.org/10.1029/2001JD001053, 2002.

Dal Maso, M., Kulmala, M., Riipinen, I., Wagner, R., Hussein, T., Aalto, P. P., and Lehtinen, K. E. J.: Formation and growth of fresh atmospheric aerosols: Eight years of aerosol size distribution data from SMEAR II, Hyytiälä, Finland, Boreal Environ. Res., 10, 323-336, 2005.

Dall'Osto, M., Beddows, D. C. S., Pey, J., Rodriguez, S., Alastuey, A., Harrison, R. M., and Querol, X.: Urban aerosol size distributions over the Mediterranean city of Barcelona, NE Spain, Atmos. Chem. Phys., 12, 10693-10707, https://doi.org/10.5194/acp-12-10693-2012, 2012.

Dall'Osto, M., Querol, X., Alastuey, A., O’Dowd, C., Harrison, R. M., Wenger, J., and Gómez-Moreno, F. J.: On the spatial distribution and evolution of ultrafine particles in Barcelona, Atmos. Chem. Phys., 13, 741-759, https://doi.org/10.5194/acp-13-7412013, 2013.

Dall'Osto, M., Beddows, D. C. S., Asmi, A., Poulain, L., Hao, L., Freney, E., Allan, J. D., Canagaratna, M., Crippa, M., Bianchi, F., de Leeuw, G., Eriksson, A., Swietlicki, E., Hansson, H. C., Henzing, J. S., Granier, C., Zemankova, K., Laj, P., Onasch, T., Prevot, A., Putaud, J. P., Sellegri, K., Vidal, M., Virtanen, A., Simo, R., Worsnop, D., O’Dowd, C., Kulmala, M., and Harrison, R. M.: Novel insights on new particle formation derived from a pan-european observing system, Sci. Rep., 8, 1482 https://doi.org/10.1038/s41598-017-17343-9, 2018.

Dall'Osto, M., Thorpe, A., Beddows, D. C. S., Harrison, R. M., Barlow, J. F., Dunbar, T., Williams, P. I., and Coe, H.: Remarkable dynamics of nanoparticles in the urban atmosphere, Atmos. Chem. Phys., 11, 6623-6637, https://doi.org/10.5194/acp11-6623-2011, 2011.

Dall'Osto, M., Beddows, D. C. S., Tunved, P., Krejci, R., Ström, J., Hansson, H. C., Yoon, Y. J., Park, K. T., Becagli, S., Udisti, R., Onasch, T., Ódowd, C. D., Simó, R., and Harrison, R. M.: Arctic sea ice melt leads to atmospheric new particle formation, Sci. Rep., 7, 1-10, 2017.

Dameto de España, C., Wonaschütz, A., Steiner, G., Rosati, B., Demattio, A., Schuh, H., and Hitzenberger, R.: Long-term quantitative field study of New Particle Formation (NPF) events as a source of Cloud Condensation Nuclei $(\mathrm{CCN})$ in the urban background of Vienna, Atmos. Environ., 164, 289-298, 2017.

Davidson, C. I., Phalen, R. F., and Solomon, P. A.: Airborne particulate matter and human health: A review, Aerosol Sci. Tech., 39, 737-749, 2005.

Draxler, R. R. and Hess, G. D.: An Overview of the HYSPLIT_4 Modelling System for Trajectories, Dispersion, and Deposition, Australian Meteorolog. Mag., 47, 295-308, 1998.

Ehn, M., Vuollekoski, H., Petäjä, T., Kerminen, V.-M., Vana, M., Aalto, P., de Leeuw, G., Ceburnis, D., Dupuy, R., O’Dowd, C. D., and Kulmala, M.: Growth rates during coastal and marine new particle formation in western Ireland, J. Geophys. Res., 115, D18218, https://doi.org/10.1029/2010JD014292, 2010.

Fiedler, V., Dal Maso, M., Boy, M., Aufmhoff, H., Hoffmann, J., Schuck, T., Birmili, W., Hanke, M., Uecker, J., Arnold, F., and Kulmala, M.: The contribution of sulphuric acid to atmospheric particle formation and growth: a comparison between boundary layers in Northern and Central Europe, Atmos. Chem. Phys., 5, 1773-1785, https://doi.org/10.5194/acp-5-1773-2005, 2005.

Fuchs, N. A. and Sutugin, A. G.: Highly Dispersed Aerosols, Foreign Sci. and Technol. Center, 1-86, 1971.

Gentner, D. R., Isaacman, G., Worton, D. R., Chan, A. W. H., Dallmann, T. R., Davis, L., Liu, S., Day, D. A., Russell, L. M., Wilson, K. R., Weber, R., Guha, A., Harley, R. A., and Goldstein, A. H.: Elucidating secondary organic aerosol from diesel and gasoline vehicles through detailed characterization of organic carbon emissions, P. Natl. Acad. Sci. USA, 109, 18318-18323, 2012.

Hama, S. M. L., Cordell, R. L., Kos, G. P. A., Weijers, E. P., and Monks, P. S.: Sub-micron particle number size distribution char- 
acteristics at two urban locations in Leicester, Atmos. Res., 194, 1-16, 2017.

Harrison, R. M.: Urban atmospheric chemistry: a very special case for study, npj Climate and Atmos. Sci., 1, 5, https://doi.org/10.1038/s41612-017-0010-8, 2017.

Harrison, R. M., Shi, J. P., Xi, S., Khan, A., Mark, D., Kinnersley, R., and Yin, J.: Measurement of number, mass and size distribution of particles in the atmosphere, Philos. T. Roy. Soc. A, 358, 2567-2580, 2000.

Harrison, R. M., Yin, J., Tilling, R. M., Cai, X., Seakins, P. W., Hopkins, J. R., Lansley, D. L., Lewis, A. C., Hunter, M. C., Heard, D. E., Carpenter, L. J., Creasey, D. C., Lee, J. D., Pilling, M. J., Carslaw, N., Emmerson, K. M., Redington, A., Derwent, R. G., Ryall, D., Mills, G., and Penkett, S. A., Measurement and Modelling of Air Pollution and Atmospheric Chemistry in the UK West Midlands Conurbation: Overview of the PUMA Consortium Project, Sci. Total Environ., 360, 5-25, 2006.

Harrison, R. M., Beddows, D. C. S., Alam, M. S., Singh, A., Brean, J., Xu, R., Kotthaus, S., and Grimmond, S.: Interpretation of particle number size distributions measured across an urban area during the FASTER campaign, Atmos. Chem. Phys., 19, 39-55, https://doi.org/10.5194/acp-19-39-2019, 2019.

Hietikko, R., Kuuluvainen, H., Harrison, R. M., Portin, H., Timonen, H., Niemi, J. V., and Ronkko, T.: Diurnal variation of nanocluster aerosol concentrations and emission factors in a street canyon, Atmos. Environ., 189, 98-106, 2018.

Iida, K., Stolzenburg, M. R., McMurry, P. H., and Smith, J. N.: Estimating nanoparticle growth rates from size-dependent charged fractions: Analysis of new particle formation events in Mexico City, J. Geophys. Res.-Atmos. 113, D05207, https://doi.org/10.1029/2007JD009260, 2008.

Jayaratne, R., Pushpawela, B., He, C., Li, H., Gao, J., Chai, F., and Morawska, L.: Observations of particles at their formation sizes in Beijing, China, Atmos. Chem. Phys., 17, 8825-8835, https://doi.org/10.5194/acp-17-8825-2017, 2017.

Jeong, C.-H., Evans, G. J., McGuire, M. L., Chang, R. Y.-W., Abbatt, J. P. D., Zeromskiene, K., Mozurkewich, M., Li, S.M., and Leaitch, W. R.: Particle formation and growth at five rural and urban sites, Atmos. Chem. Phys., 10, 7979-7995, https://doi.org/10.5194/acp-10-7979-2010, 2010.

Kalkavouras, P., Bossioli, E., Bezantakos, S., Bougiatioti, A., Kalivitis, N., Stavroulas, I., Kouvarakis, G., Protonotariou, A. P., Dandou, A., Biskos, G., Mihalopoulos, N., Nenes, A., and Tombrou, M.: New particle formation in the southern Aegean Sea during the Etesians: importance for $\mathrm{CCN}$ production and cloud droplet number, Atmos. Chem. Phys., 17, 175-192, https://doi.org/10.5194/acp-17-175-2017, 2017.

Kecorius, S., Kivekäs, N., Kristensson, A., Tuch, T., Covert, D. S., Birmili, W., Lihavainen, H., Hyvärinen, A. P., Martinsson, J., Sporre, M. K., Swietlicki, E., Wiedensohler, A., and Ulevicius, V.: Significant increase of aerosol number concentrations in air masses crossing a densely trafficked sea area, Oceanologia, 58, 1-12, 2016.

Kelly, F. J. and Fussell, J. C.: Size, source and chemical composition as determinants of toxicity attributable to ambient particulate matter, Atmos. Environ., 60, 504-526, 2012.

Keuken, M. P., Moerman, M., Zandveld, P., Henzing, J. S., and Hoek, G.: Total and size-resolved particle number and black carbon concentrations in urban areas near Schiphol airport (the Netherlands), Atmos. Environ., 104, 132-142, 2015.

Kirkby, J., Curtius, J., Almeida, J., Dunne, E., Duplissy, J., Ehrhart, S., Franchin, A., Gagné, S., Ickes, L., Kürten, A., Kupc, A., Metzger, A., Riccobono, F., Rondo, L., Schobesberger, S., Tsagkogeorgas, G., Wimmer, D., Amorim, A., Bianchi, F., Breitenlechner, M., David, A., Dommen, J., Downard, A., Ehn, M., Flagan, R. C., Haider, S., Hansel, A., Hauser, D., Jud, W., Junninen, H., Kreissl, F., Kvashin, A., Laaksonen, A., Lehtipalo, K., Lima, J., Lovejoy, E.R., Makhmutov, V., Mathot, S., Mikkilä, J., Minginette, P., Mogo, S., Nieminen, T., Onnela, A., Pereira, P., Petäjä, T., Schnitzhofer, R., Seinfeld, J. H., Sipilä, M., Stozhkov, Y., Stratmann, F., Tomé, A., Vanhanen, J., Viisanen, Y., Vrtala, A., Wagner, P. E., Walther, H., Weingartner, E., Wex, H., Winkler, P. M., Carslaw, K. S., Worsnop, D. R., Baltensperger, U., and Kulmala, M.:: Role of sulphuric acid, ammonia and galactic cosmic rays in atmospheric aerosol nucleation, Nature, 476, 429-435, 2011.

Kirkby, J., Curtius, J., Almeida, J., Dunne, E., Duplissy, J., Ehrhart, S., Franchin, A., Gagne, S., Ickes, L., Kurten, A., Kupc, Metzger, A., Riccobono, F., Rondo, L., Schobesberger, S., Tsagkogeorgas, G., Wimmer, D., Amorim, A. A., Bianchi, F., Breitenlechner, M., David, A., Dommen, J., Downard, A., Ehn, M., Flagan, R. C., Haider, S., Hansel, A., Hauser, D., Jud, W., Junninen, H., Kreiss, F., Kvashin, A., Laaksonen, A., Lehtipalo, K., Lima, J., Lovejoy, E. R., Makhmutov, V., Mathot, S., Mikkila, J., Minginette, P., Mogo, S., Nieminen, T., Onnela, A., Pereira, P., Petaja, T., Schnitzhofer, R., Seinfeld, J. H., Sipila, M., Stozhkov, Y., Stratmann, F., Tome, A., Vanhanen, J., Viisanen, Y., Vrtala, A., Wagner, P. E., Walther, H., Weingartner, E., Wex, H., Winkler, P. M., Carslaw, K. S., Worsnop, D. R., Baltensperger, U., and Kulmala, M.: Ion-induced nucleation of pure biogenic particles, Nature, 533, 521-526, 2016.

Korhonen, P., Kulmala, M., Laaksonen, A., Viisanen, Y., Mcgraw, R., and Seinfeld, J. H.: Ternary nucleation of $\mathrm{H}_{2} \mathrm{SO}_{4}, \mathrm{NH}_{3}$ and $\mathrm{H}_{2} \mathrm{O}$ in the atmosphere, J. Geophys. Res., 104, 26349-26353, 1999.

Kuang, C., McMurry, P. H., McCormick, A. V., and Eisele, F. L.: Dependence of nucleation rates on sulfuric acid vapor concentration in diverse atmospheric locations, J. Geophys. Res.-Atmos., 113, D10209, https://doi.org/10.1029/2007JD009253, 2008.

Kulmala, M., Dal Maso, M., Mäkelä, J. M., Pirjola, L., Väkevä, M., Aalto, P., Miikkulainen, P., Hämeri, K., and O'Dowd, C. D.: On the formation, growth and composition of nucleation mode particles, Tellus B, 53, 479-490, 2001.

Kulmala, M., Petäjä, T., Mönkkönen, P., Koponen, I. K., Dal Maso, M., Aalto, P. P., Lehtinen, K. E. J., and Kerminen, V.-M.: On the growth of nucleation mode particles: source rates of condensable vapor in polluted and clean environments, Atmos. Chem. Phys., 5, 409-416, https://doi.org/10.5194/acp-5-409-2005, 2005.

Kulmala, M., Kontkanen, J., Junninen, H., Lehtipalo, K., Manninen, H. E., Nieminen, T., Petaja, T., Sipila, M., Schobesberger, S., Rantala, P., Franchin, A., Jokinen, T., Jarvinen, E., Aijala, M., Kangasluoma, J., Hakala, J., Aalto, P. P., Paasonen, P., Mikkila, J., Vanhanen, J., Aalto, J., Hakola, H., Makkonen, U., Ruuskanen, T., Mauldin, R. L., Duplissy, J., Vehkamaki, H., Back, J., Kortelainen, A., Riipinen, I., Kurten, T., Johnston, M. V., Smith, J. N., Ehn, M., Mentel, T. F., Lehtinen, K. E. J., Laaksonen, A., Kerminen, V.-M., and Worsnop, D. R.: Direct Observations of Atmospheric Aerosol Nucleation, Science, 339, 943-946, 2013. 
Kulmala, M., Petäjä, T., Ehn, M., Thornton, J., Sipilä, M., Worsnop, D. R., and Kerminen, V.-M.: Chemistry of Atmospheric Nucleation: On the Recent Advances on Precursor Characterization and Atmospheric Cluster Composition in Connection with Atmospheric New Particle Formation, Ann. Rev. Phys. Chem., 65, 21-37, 2014.

Kulmala, M., Luoma, K., Virkkula, A., Petäjä, T., Paasonen, P., Kerminen, V. M., Nie, W., Qi, X., Shen, Y., Chi, X., and Ding, A.: On the mode-segregated aerosol particle number concentration load: Contributions of primary and secondary particles in Hyytiälä and Nanjing, Boreal Environ. Res., 21, 319-331, 2016.

Kulmala, M., Kerminen, V.-M., Petäjä, T., Ding, A. J., and Wang, L.: Atmospheric gas-to-particle conversion: why NPF events are observed in megacities?, Faraday Discuss., 200, 271-288, 2017.

Kulmala, M., Petäjä, T., Nieminen, T., Sipilä, M., Manninen, H. E., Lehtipalo, K., Dal Maso, M., Aalto, P. P., Junninen, H., Paasonen, P., Riipinen, I., Lehtinen, K. E. J., Laaksonen, A., and Kerminen, V. M.: Measurement of the nucleation of atmospheric aerosol particles, Nat. Protoc., 7, 1651-1667, 2012.

Kulmala, M., Vehkamäki, H., Petäjä, T., Dal Maso, M., Lauri, A., Kerminen, V. M., Birmili, W., and McMurry, P. H.: Formation and growth rates of ultrafine atmospheric particles: A review of observations, J. Aerosol Sci., 35, 143-176, 2004.

Kuuluvainen, H., Kannosto, J., Virtanen, A., Mäkelä, J. M., Kulmala, M., Aalto, P., and Keskinen, J.: Technical Note: Measuring condensation sink and ion sink of atmospheric aerosols with the electrical low pressure impactor (ELPI), Atmos. Chem. Phys., 10, 1361-1368, https://doi.org/10.5194/acp-101361-2010, 2010.

Laaksonen, A., Kulmala, M., O’Dowd, C. D., Joutsensaari, J., Vaattovaara, P., Mikkonen, S., Lehtinen, K. E. J., Sogacheva, L., Dal Maso, M., Aalto, P., Petäjä, T., Sogachev, A., Yoon, Y. J., Lihavainen, H., Nilsson, D., Facchini, M. C., Cavalli, F., Fuzzi, S., Hoffmann, T., Arnold, F., Hanke, M., Sellegri, K., Umann, B., Junkermann, W., Coe, H., Allan, J. D., Alfarra, M. R., Worsnop, D. R., Riekkola, M.-L., Hyötyläinen, T., and Viisanen, Y.: The role of VOC oxidation products in continental new particle formation, Atmos. Chem. Phys., 8, 2657-2665, https://doi.org/10.5194/acp-8-2657-2008, 2008.

Ma, N. and Birmili, W.: Estimating the contribution of photochemical particle formation to ultrafine particle number averages in an urban atmosphere, Sci. Total Environ., 512, 154-166, 2015.

MacNee, W. and Donaldson, K.: Mechanism of lung injury caused by $\mathrm{PM}_{10}$ and ultrafine particles with special reference to COPD, Europ. Respirat. J., 21, 47-51, 2003.

Makkonen, R., Asmi, A., Kerminen, V.-M., Boy, M., Arneth, A., Hari, P., and Kulmala, M.: Air pollution control and decreasing new particle formation lead to strong climate warming, Atmos. Chem. Phys., 12, 1515-1524, https://doi.org/10.5194/acp12-1515-2012, 2012.

Masiol, M., Harrison, R. M., Vu, T. V., and Beddows, D. C. S.: Sources of sub-micrometre particles near a major international airport, Atmos. Chem. Phys., 17, 12379-12403, https://doi.org/10.5194/acp-17-12379-2017, 2017.

Merikanto, J., Spracklen, D. V., Mann, G. W., Pickering, S. J., and Carslaw, K. S.: Impact of nucleation on global CCN, Atmos. Chem. Phys., 9, 8601-8616, https://doi.org/10.5194/acp-9-86012009, 2009.
Metzger, A., Verheggen, B., Dommen, J., Duplissy, J., Prevot, A. S. H., Weingartner, E., Riipinen, I., Kulmala, M., Spracklen, D. V., Carslaw, K. S., and Baltensperger, U.: Evidence for the role of organics in aerosol particle formation under atmospheric conditions, P. Natl. Acad. Sci. USA, 107, 6646-6651, 2010.

Minguillón, M. C., Brines, M., Pérez, N., Reche, C., Pandolfi, M., Fonseca, A. S., Amato, F., Alastuey, A., Lyasota, A., Codina, B., Lee, H. K., Eun, H. R., Ahn, K. H., and Querol, X.: New particle formation at ground level and in the vertical column over the Barcelona area, Atmos. Res., 164, 118-130, 2015.

Napari, I., Noppel, M., Vehkamäki, H., and Kulmala, M.: An improved model for ternary nucleation of sulfuric acid-ammoniawater, J. Chem. Phys., 116, 4221-4227, 2002.

Németh, Z. and Salma, I.: Spatial extension of nucleating air masses in the Carpathian Basin, Atmos. Chem. Phys., 14, 8841-8848, https://doi.org/10.5194/acp-14-8841-2014, 2014.

Németh, Z., Rosati, B., Zíková, N., Salma, I., Bozó, L., Dameto de España, C., Schwarz, J., Ždímal, V., and Wonaschütz, A.: Comparison of atmospheric new particle formation events in three Central European cities, Atmos. Environ., 178, 191-197, 2018.

Nieminen, T., Kerminen, V.-M., Petäjä, T., Aalto, P. P., Arshinov, M., Asmi, E., Baltensperger, U., Beddows, D. C. S., Beukes, J. P., Collins, D., Ding, A., Harrison, R. M., Henzing, B., Hooda, R., Hu, M., Hõrrak, U., Kivekäs, N., Komsaare, K., Krejci, R., Kristensson, A., Laakso, L., Laaksonen, A., Leaitch, W. R., Lihavainen, H., Mihalopoulos, N., Németh, Z., Nie, W., O'Dowd, C., Salma, I., Sellegri, K., Svenningsson, B., Swietlicki, E., Tunved, P., Ulevicius, V., Vakkari, V., Vana, M., Wiedensohler, A., Wu, Z., Virtanen, A., and Kulmala, M.: Global analysis of continental boundary layer new particle formation based on longterm measurements, Atmos. Chem. Phys., 18, 14737-14756, https://doi.org/10.5194/acp-18-14737-2018, 2018.

Nilsson, E. D., Paatero, J., and Boy, M.: Effects of air masses and synoptic weather on aerosol formation in the continental boundary layer, Tellus B, 53, 462-478, 2001.

Oberdurster, G.: Toxicology of ultrafine particles: in vivo studies, Philos. T. Roy. Soc. A, 358, 2719-2740, 2000.

O’Dowd, C. D., Aalto, P., Hmeri, K., Kulmala, M., and Hoffmann, T.: Atmospheric particels from organic vapours, Nature, 416, 497-498, 2002.

O’Dowd, C. D., Jimenez, J. L., Bahreini, R., Flagan, R. C., Seinfeld, J. H., Hameri Kaarle, Pirjola, L., Kulmala, M., Gerard Jennings, S., and Hoffmann, T.: Marine aerosol formation from biogenic iodine emissions, Nature, 417, 1-5, 2002.

Park, M., Yum, S. S., and Kim, J. H.: Characteristics of submicron aerosol number size distribution and new particle formation events measured in Seoul, Korea, during 2004-2012, AsiaPacific, J. Atmos. Sci., 51, 1-10, 2015.

Peng, Y., Dong, Y., Li, X., Liu, X., Dai, J., Chen, C., Dong, Z., Du, C., and Wang, Z.: Different Characteristics of New Particle Formation Events at Two Suburban Sites in Northern China, Atmosphere, 8, 58, https://doi.org/10.3390/atmos8120258, 2017.

Penttinen, P., Timonen, K. L., Tiittanen, P., Mirme, A., Ruuskanen, J., and Pekkanen, J.: Number concentration and size of particles in urban air: Effects on spirometric lung function in adult asthmatic subjects, Environ. Health Perspect., 109, 319-323, 2001.

Petäjä, T., Mauldin, III, R. L., Kosciuch, E., McGrath, J., Nieminen, T., Paasonen, P., Boy, M., Adamov, A., Kotiaho, T., and Kulmala, M.: Sulfuric acid and $\mathrm{OH}$ concentrations in a boreal forest site, 
Atmos. Chem. Phys., 9, 7435-7448, https://doi.org/10.5194/acp9-7435-2009, 2009.

Pikridas, M., Sciare, J., Freutel, F., Crumeyrolle, S., von der Weiden-Reinmüller, S.-L., Borbon, A., Schwarzenboeck, A., Merkel, M., Crippa, M., Kostenidou, E., Psichoudaki, M., Hildebrandt, L., Engelhart, G. J., Petäjä, T., Prévôt, A. S. H., Drewnick, F., Baltensperger, U., Wiedensohler, A., Kulmala, M., Beekmann, M., and Pandis, S. N.: In situ formation and spatial variability of particle number concentration in a European megacity, Atmos. Chem. Phys., 15, 10219-10237, https://doi.org/10.5194/acp-15-10219-2015, 2015.

Politis, M., Pilinis, C., and Lekkas, T. D.: Ultrafine particles (UFP) and health effects, Dangerous, Like no other PM?, Review and analysis, Global Nest J., 10, 439-452, 2008.

Rahman, M. M., Mazaheri, M., Clifford, S., and Morawska, L.: Estimate of main local sources to ambient ultrafine particle number concentrations in an urban area, Atmos. Res., 194, 178-189, 2017.

Riccobono, F., Schobesberger, S., Scott, C. E., Dommen, J., Ortega, I. K., Rondo, L., Almeida, J., Amorim, A., Bianchi, F., Breitenlechner, M., David, A., Downard, A., Dunne, E. M., Duplissy, J., Ehrhart, S., Flagan, R. C., Franchin, A., Hansel, A., Junninen, H., Kajos, M., Keskinen, H., Kupc, A., Makhmutov, V., Mathot, S., Nieminen, T., Onnela, A., Petäjä, T., Tsagkogeorgas, G., Vaattovaara, P., Viisanen, Y., Vrtala, A., and Wagner, P. E.: Oxidation Products of Biogenic Atmospheric Particles, Science, 717, 17722, 2014

Riipinen, I., Sihto, S.-L., Kulmala, M., Arnold, F., Dal Maso, M., Birmili, W., Saarnio, K., Teinilä, K., Kerminen, V.-M., Laaksonen, A., and Lehtinen, K. E. J.: Connections between atmospheric sulphuric acid and new particle formation during QUEST III-IV campaigns in Heidelberg and Hyytiälä, Atmos. Chem. Phys., 7, 1899-1914, https://doi.org/10.5194/acp-7-1899-2007, 2007.

Robinson, A. L., Donahue, N. M., Shrivastava, M. K., Weitkamp, E. A., Sage, A. M., Grieshop, A. P., Lane, T. E., Pierce, J. R., and Pandis, S. N.: Rethinking Organic Aerosols?, Science, 315, 1259-1262, 2007.

Rönkkö, T., Kuuluvainen, H., Karjalainen, P., Keskinen, J., Hillamo, R., Niemi, J. V., Pirjola, L., Timonen, H. J., Saarikoski, S., Saukko, E., Järvinen, A., Silvennoinen, H., Rostedt, A., Olin, M., Yli-Ojanperä, J., Nousiainen, P., Kousa, A., and Dal Maso, M.: Traffic is a major source of atmospheric nanocluster aerosol, $\mathrm{P}$. Natl. Acad. Sci. USA, 114, 7549-7554, 2017.

Salma, I., Borsós, T., Németh, Z., Weidinger, T., Aalto, P., and Kulmala, M.: Comparative study of ultrafine atmospheric aerosol within a city, Atmos. Environ., 92, 154-161, 2014.

Salma, I., Németh, Z., Kerminen, V.-M., Aalto, P., Nieminen, T., Weidinger, T., Molnár, Á., Imre, K., and Kulmala, M.: Regional effect on urban atmospheric nucleation, Atmos. Chem. Phys., 16, 8715-8728, https://doi.org/10.5194/acp-16-8715-2016, 2016.

Salma, I., Varga, V., and Németh, Z.: Quantification of an atmospheric nucleation and growth process as a single source of aerosol particles in a city, Atmos. Chem. Phys., 17, 1500715017, https://doi.org/10.5194/acp-17-15007-2017, 2017.

Samoli, E., Atkinson, R. W., Analitis, A., Fuller, G. W., Beddows, D., Green, D. C., Mudway, I. S., Harrison, R. M., Anderson, H. R., and Kelly, F. J.: Differential health effects of short-term ex- posure to source-specific particles in London, UK, Environ. Intl., 97, 246-253, 2016.

Seinfeld, J. H. and Pandis, S. N.: Atmospheric Chemistry and Physics: From Air Pollution to Climate Change, 3rd Ed. New Jersey, Canada, John Wiley \& Sons, Inc, 1-1152, 2012.

Shen, X., Sun, J., Kivekäs, N., Kristensson, A., Zhang, X., Zhang, Y., Zhang, L., Fan, R., Qi, X., Ma, Q., and Zhou, H.: Spatial distribution and occurrence probability of regional new particle formation events in eastern China, Atmos. Chem. Phys., 18, 587599, https://doi.org/10.5194/acp-18-587-2018, 2018.

Shi, J. P. and Harrison, R. M.: Investigation of ultrafine particle formation during diesel exhaust dilution, Environ. Sci. Technol., 33, 3730-3736, 1999.

Shi, J. P., Evans, D. E., Khan, A. A., and Harrison, R. M.: Sources and concentration of nanoparticles $(<10 \mathrm{~nm}$ diameter $)$ in the urban atmosphere, Atmos. Environ., 35, 1193-1202, 2001.

Spracklen, D. V., Carslaw, K. S., Kulmala, M., Kerminen, V. M., Sihto, S. L., Riipinen, I., Merikanto, J., Mann, G. W., Chipperfield, M. P., Wiedensohler, A., Birmili, W., and Lihavainen, H.: Contribution of particle formation to global cloud condensation nuclei concentrations, Geophys. Res. Lett., 35, 1-5, 2008.

Spracklen, D. V., Carslaw, K. S., Merikanto, J., Mann, G. W., Reddington, C. L., Pickering, S., Ogren, J. A., Andrews, E., Baltensperger, U., Weingartner, E., Boy, M., Kulmala, M., Laakso, L., Lihavainen, H., Kivekäs, N., Komppula, M., Mihalopoulos, N., Kouvarakis, G., Jennings, S. G., O’Dowd, C., Birmili, W., Wiedensohler, A., Weller, R., Gras, J., Laj, P., Sellegri, K., Bonn, B., Krejci, R., Laaksonen, A., Hamed, A., Minikin, A., Harrison, R. M., Talbot, R., and Sun, J.: Explaining global surface aerosol number concentrations in terms of primary emissions and particle formation, Atmos. Chem. Phys., 10, 4775-4793, https://doi.org/10.5194/acp-10-4775-2010, 2010.

Sutton, M. A., Place, C. J., Eager, M., Fowler, D., and Smith, R. I.: Assessment of the magnitude of ammonia emissions in the UK, Atmos. Environ., 29, 1393-1411, 1995.

Tröstl, J., Chuang, W. K., Gordon, H., Heinritzi, M., Yan, C. , Molteni, U., Ahlm, L. , Frege, C., Bianchi, F., Wagner, R., Simon, M., Lehtipalo, K., Williamson, C., Craven, J. S., Duplissy, J., Adamov, A., Almeida, J., Bernhammer, A.-K., Breitenlechner, M., Brilke, S., Dias, A., Ehrhart, S., Flagan, R. C., Franchin, A., Fuchs, C., Guida, R., Gysel, M., Hansel, A., Hoyle, C. R., Jokinen, T., Junninen, H., Kangasluoma, J., Keskinen, H., Kim, J., Krapf, M., Kürten, A., Laaksonen, A., Lawler, M., Leiminger, M., Mathot,S., Möhler, O., Nieminen, T., Onnela, A., Petäjä, T., Piel, F. M., Miettinen, P., Rissanen, M. P., Rondo, L., Sarnela, N., Schobesberger, S., Sengupta, K., Sipilä, M., Smith, J. N., Steiner, G., Tomè, A., Virtanen, A., Wagner, A. C., Weingartner, E., Wimmer, D., Winkler, P. M., Ye, P., Carslaw, K. S., Curtius, J., Dommen, J., Kirkby, J., Kulmala, M., Riipinen, I., Worsnop, D. R., Donahue, N. M., and Baltensperger, U.: The role of low-volatility organic compounds in initial particle growth in the atmosphere, Nature, 533, 527-531, 2016.

Von Bismarck-Osten, C., Birmili, W., Ketzel, M., Massling, A., Petäjä, T., and Weber, S.: Characterization of parameters influencing the spatio-temporal variability of urban particle number size distributions in four European cities, Atmos. Environ., 77, 415-429, 2013.

Wang, Z., Wu, Z., Yue, D., Shang, D., Guo, S., Sun, J., Ding, A., Wang, L., Jiang, J., Guo, H., Gao, J., Cheung, H. C., Morawska, 
L., Keywood, M., and Hu, M.: New particle formation in China: Current knowledge and further directions, Sci. Total Environ., 577, 258-266, 2017.

Wehner, B., Siebert, H., Stratmann, F., Tuch, T., Wiedensohler, A., Petäjä, T., Dal Maso, M., and Kulmala, M.: Horizontal homogeneity and vertical extent of new particle formation events, Tellus B, 59, 362-371, 2007.

Woo, K. S., Chen, D. R., Pui, D. Y. H., and McMurry, P. H.: Measurement of Atlanta aerosol size distributions: Observations of lutrafine particle events, Aerosol Sci. Tech., 34, 5-87, 2001.

Xiao, S., Wang, M. Y., Yao, L., Kulmala, M., Zhou, B., Yang, X., Chen, J. M., Wang, D. F., Fu, Q. Y., Worsnop, D. R., and Wang, L.: Strong atmospheric new particle formation in winter in urban Shanghai, China, Atmos. Chem. Phys., 15, 1769-1781, https://doi.org/10.5194/acp-15-1769-2015, 2015.
Yli-Juuti, T., Nieminen, T., Hirsikko, A., Aalto, P. P., Asmi, E., Hõrrak, U., Manninen, H. E., Patokoski, J., Dal Maso, M., Petäjä, T., Rinne, J., Kulmala, M., and Riipinen, I.: Growth rates of nucleation mode particles in Hyytiälä during 20032009: variation with particle size, season, data analysis method and ambient conditions, Atmos. Chem. Phys., 11, 12865-12886, https://doi.org/10.5194/acp-11-12865-2011, 2011.

Yue, D. L., Hu, M., Zhang, R. Y., Wang, Z. B., Zheng, J., Wu, Z. J., Wiedensohler, A., He, L. Y., Huang, X. F., and Zhu, T.: The roles of sulfuric acid in new particle formation and growth in the mega-city of Beijing, Atmos. Chem. Phys., 10, 4953-4960, https://doi.org/10.5194/acp-10-4953-2010, 2010.

Zhang, X., Zhang, Y., Sun, J., Zheng, X., Li, G., and Deng, Z.: Characterization of particle number size distribution and new particle formation in an urban environment in Lanzhou, China, J. Aerosol Sci., 103, 53-66, 2017. 